\title{
日光・中禅寺湖畔における外国人別荘地の形成 A RESEARCH OF THE FOREIGNERS COTTAGES IN LAKE CHUZENJI, NIKKO
}

\author{
伊 藤教子*, 初田亨** \\ Noriko ITO and Tohru HATSUDA
}

\begin{abstract}
Lake Chuzenji in Nikko is one of the famous foreigners resort that became prosperous from Meiji Era in Japan. Several cottages are now on existing, but recently Lakeside area is more famous sight seeing spot than foreigners resort. The foreigner cottage area of Chuzenji lakeside is formed around the minister and the diplomats from opportunity, the 21st year of Meiji, and it grows to be a scale that it is called with the foreigner cottage zone in opportunity, the 30 th year of Mei $j i$. An embassy cottage was built, too, and a cottage had the character that moved the foreigner of the minister and the diplomats upper classes to the center except for the individual cottage. "Tokyo Angling and Country Club" of the "Marunuma Fishing Club" rest which aimed at the amusement which was characteristic of the foreigner of Fly-Fishing is made in Showa term since Taisho end. It has a role as a place of the interchange of the diplomats and Japanese upper class people. There was a reason that the most part of the cottage owner of Chuzenji lakeside was a foreigner, too, and fell into the decline with war's beginning.
\end{abstract} Keyword: Nikko, Lake Chuzenji, Foreigners Cottages, Tokyo Angling and Country Club,
The Minister and The Diplomats

日光, 中禅寺湖, 外国人別荘, 東京アソグリングエンドがリリークラブ, 公使と外交官

\section{はじめに}

明治維新における神仏分離令以前の中禅寺湖は、中禅寺上人の支 配する神域であった。訪問者は男体山を中心とする諸行事の期間中 に登山する修験者がほとんどで、信仰を中心とするものであった。 また中禅寺湖には、日光町方の者が権利を持って茶屋を営業してい た。明治維新後は、それまでの中禅寺の名称は中宮祠と改められ、 茶屋の権利を持っていた日光町の人達が、二荒山神社の土地を借り て、茶屋の経営を引き続き行っていた。

明治 5 年(1872)に男体山の女人禁制が解かれると、山岳修行者だ けではなく、日本人観光客のほが、諸外国の外交官が婦人または 家族連れで、中禅寺湖や華絠滝などの見学に登山するようになった。 幕政時代のような爰格な修行の形態はくずれていき、観光地として 発展し始め、食堂や土産店などが出現していった。また中禅寺湖畔 一体は、明治 17 年(1884)に御橅場に、さらに明治 20 年(1887)には 御料地として指定されている。これにより、中絣寺湖畔一体の土地 はすべて、宮内省および二荒山神社、輪王寺の所有となった。この 頃から、外国人によって別荘も建てられていく。

大正年代に入ると、奥日光方面一の旅客収容策が急速に打ち出さ れ、交通機関を充奉させて遊覧施設等が完備され、観光地、そして 別荘地としてさらに発展を遂げていく。その後、昭和 9 年 (1934) には国立公園の指定を受け、現在に至っている。

中禅寺湖畔の外国人別䓅については、『日光市史』1)、『日本別荘 史ノ一ト』2)、『大日光』 ${ }^{3)}$ などに断片的に語られているが、その 全体像については明らかにされていない。現在は外国人別荘の多く
が失われてしまっているが、中禅寺湖畔の別荘地としての歴史は古 く、軽井沢と並ぶ歴史を持っており ${ }^{4)}$ 、日本の別荘地開発を考える 上で欠くことの出来ない存在と言える。本稿では、史料およびヒア リングなどを通して、中禅寺湖畔こ外国人別甠地汧成された事実と、 その発展経緯 およびその内容、特性を明らがすることで、現在開発 が准められつある中禅寺湖畔の、今後の開発について参考ともなる 資料を作成少ここを目的としている。

\section{1. 中禅寺湖畔宿泊施設の歴史}

山岳修行の人しか足を踏み入れない中絣寺湖畔に、最初の茶屋が 出来たのは寛保元年 (1741) で、四軒の茶屋が作られ、その後6 軒 に増えている。明治 5 年(1872) に男体山の女人禁制が解かるるる、 明治 10 年(1877) 前後より、登山者のための宿泊施設の必要性が生 じ、中禅寺湖畔には、中禅寺社殿付近と暮浦分泜付近にあった、六 軒の茶屋の者達が宿泊に必要な施設をつくり、次第に旅館の形式を 整えていった。その後、場所を移転する旅館も現れたが、6軒の茶 屋のうち、蔦屋と米屋の 2 軒が今でも営業を続けている5)。

日光に外国人ホテルが開業したのは明治初期で、明治 4 年 (1871) の鈴木ホテル、明治 6 年 (1873) の金谷カッテージインがある6)。 明治 18 年 (1885) には東京・宇都宮間の鉄道が開通し、さらに明 治 22 年 (1889) には、馬返・中禅寺間の山道に九十九折の新道が 開拓された。そしてその直後の明治 27 年 (1894) には、中禅寺湖 畔に外国人専用のレーキサイドホテルが創業している7)。

レーキサイドホテルは、創業当初から外国人専用のホテルとして 
計画されていた。外国人専用ホテルが早い時期から営業していた箱 根では、富士屋旅館が外国人専用、奈良屋旅館が日本人専用と、内々

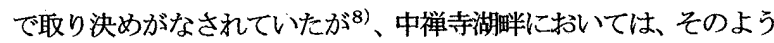
な協定はなかった。しかし、レーキサイドホテルが外国人客、他の 旅館が日本人客と区分されていた。特に、レ一キサイドホテル二代 目の坂巻正明の時には、浴衣で建物内を歩き回る日本人客を嫌い、 空室があっても日本人客を断るなど、本格的なホテルにこだわりを もって営業していたと言う。また、日光金谷ホテルが自家発電機で 発電を行っていたのと同様、レーキサイドホテルでも自家発電所を ホテルの裏側に設け発電しており、その余剩電力を中宮祠の人々に 売却していたともいう ${ }^{9)}$ 。

ホテルの経営は、坂巻正太郎、正明、栄一氏と 3 代続いた後、第 二次世界大戦後は、一時期イギリス軍に接収され、また昭和 40 年 （1965）に東武鉄道に売却された。明治から大正時代にかけては、 外交官や公使、大使などが宿泊客のほとんどを占めており、また、 外国人別荘が減り始めた戦後も、宿泊客の9 割以上は外国人であっ たが、東武鉄道に経営が移されてからは、日本人観光客が宿泊客の ほとんどになっているという ${ }^{10)}$

昭和 15 年 (1940) 7 月には、国際観光ホテルとして、日光観光 ホテルがつくられている。中禅寺湖に国際観光ホテルが建設された 理由には、昭和 6 年 (1931) に公布された国立公園法による日光の 国立公園指定があったことや、日光が昭和 15 年 (1940) の、オリ ンピック大会冬季会場候補地のひとつとなっていたことが考えら れる。『日光市史』は、杤木県が作成した、冬季オリンピック開催 候補に伴う事業計画について、次のように記している ${ }^{11)}$

昭和十年 (一九三五) には日光町、杤木県体育協会が第五回冬季才リン ピック候補地としての会場誘致運動をしている。中禅寺湖付近、童頭・ 戦場ヶ原一帯、湯元の三ヶ所にスキ一施設を開設、昭和十一年（一九三 六）には第三回県下スキー大会、第八回明治神宮大会予選・全日本スキ 一大会を開催するとともに、杤木県が金精峠・白根山中間付近にスキー 小屋、菖蒲が浜に観光ホテル建設などの宿泊施設、日光道路改修、舗装、 細尾から中宫詞まで道路新設舖装等の具体化計画を出すにいたった。

日光観光ホテルの経営は、金谷ホテル株式会社にまかされ、金谷 正生が支配人になった ${ }^{12)}$ 。

\section{2. 明治期の外国人別荘地}

明治7 年 (1874) に、日本政府より外国人遊歩の許可がおりたことか ら、日光、中敌寺湖への外国人の訪問者は増加していらた。明治初期に 中禅寺湖畔を訪れた外国人避暑客は、湖畔の旅荘や輪王寺等の宿坊 に宿泊していた。明治 18 年 (1885) には，先に述べたように東京・ 宇都宮間の鉄道力潤通しており、以後、日光を訪机る外国人が急增して いる (表 1 )。それに伴、奥日光、中禅寺湖入足を伸ばす外国人も増え たと考えられる。

表 1 外国人来晃者数

\begin{tabular}{|c|c|c|}
\hline 年 畀 & 西 箮 & 来晃外国人数 \\
\hline 明治 15 & 1882 & 168 人 \\
\hline 明治18 & 1885 & 553 人 \\
\hline 明治20 & 1887 & 1199 人 \\
\hline 明治22 & 1889 & 1351 人 \\
\hline 明治 23 & 1890 & 1741 人 \\
\hline 明治 24 & 1891 & 1928人 \\
\hline
\end{tabular}

『日光市史』 ${ }^{13)}$ より作成
中禅寺湖㫠に外国人か柺性を持つようになったのは、明治中頃からで、 ベルギ一公使夫人エリアノーラ・メアリー・ダヌタンの明治27 年 (1894) 8月27日の日記によ次のように記されている ${ }^{14)}$ 。

アルベールとー緒て中禅寺に向けて九㭙こ壮発する。申し分のなと気で、急 流の緑胫沿って人力車て山登って行く旅㤬くすばらしかった。途中の茶屋

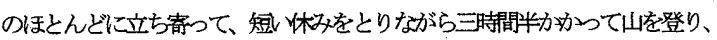

一時少し前にカークウッドの日本式の家に着、た。この家は中禅寺西膘人が

建てた最初榢で、湖崖こ建っている。

明治25年 (1892) に 政府は土地または家屋を所有する外国人の調查 を行っている。その報告書『外国人ニシテ日本人名義ヨ以ッテ土地又 家屋习所有スルモノノ調查』には、外国人所有土地家屋営業便覽一擥表】 として、日光地区の家屋の所有者につい、英国人アレキサンドル・カ 一クード、伊国人イフ・ビヤショ子、朄人リンズレー、朄人エーブ ル、独国人スクリッパの5人を記载している。 5 人のうち、中繟寺湖胖 の家剭所有者は次の通りである ${ }^{15)}$ 。

所有者 英国人アレキサンドル・カークード

物件家屋一棟 建评四十五坪

目的 住宅

所在地 日光中宮㧫司二荒山神地

名義人 中宮闹 井上保三郎

このアレキサンドル・カークードとは、トーマス・グラバーと共に 觀䊁ビールの前身であるビール会社 「゙゙ャパン・ブリュワリー・カンパ ニ一・リミテッド」の設立に貢献した 英国人法律家ウィリアム・M・ $\mathrm{H} ・$ カークードのことである。

この別甠については、明治26年 (1893) 11 月 18 日付の『下野新聞』 に次のような記載がある。

外人が各国の名勝を選み婢妾れい愫の名を以って別荤を設け土地を 有する等の怪事は往々見閆する処なるが県下日光中宮翮にも二ヶ所 の家屋を有するものあり、其一は今を去る五六年前の建築にして同 地湖水の北岸即ち日光町より登りて湖边に出る道路と湖水の間にし て日本風の高楼なり、地所は二荒山神社境内になるを同地旅店米屋 政平の名を以って借請け一为年地料其他米屋の外人上り受領する金 額二百五十円なりと云ふ而して十力月の後には挙げて米屋に奇付す るの約ありとも伝へり此所有人注司法省御彺カークード氏なりとす 他の一所は同じく湖辺の字大崎と伝える湯元道に沿える処にして 御料地内に属寸是も米屋政平の名前にして借地し前のカークード氏 の周旋にて設けたる英国代理行使某氏の別庄本年の新築に係れり二 者とも湖水の北岸にして眺望最も佳なる処にあり邦人をして羡望に 堪えざらしむる宏壮美霹の建築何れも東京火级保险会社の保険付な り

記事から判断すると、湖判には2軒の別泩があり、そのうち一軒は明 治20 年 (1887) もしくは、明治21 年 (1888) の建設、他の一軒法明治 26 年 (1893) に建設されたことがわかる。なおここには カークードの 別㢈が「米屋政平」を仲介者としていることが記されており、当時外国 人には土地家屋所有が認められていなかたため、日本人を仲介者にし て別胜を構えていたらしいことがわかる。

その後、明治 26 年 (1893) から明治 32 年 (1899) における、中禅寺 湖畔での避暑生活につい、アーネスト・サトウやエリアノーラ・メア リー・ダメタンらが日記に細かな詔术を残している ${ }^{16)}$ 。2人の日記から 外国人別甠の数を抽出すると表2のようになる。表に記した品睛は、日 記記载されたもののうち、持ち主のわかる別痤のみで、この他にも外 国人别甠は存在していた。 
アーネスト・サトウの日記には、彼自身の別牲が記されている ${ }^{17}$ 。 (明治28年8月20日)

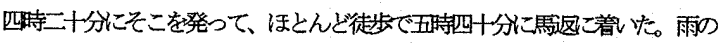
中を六時十分にそこを発ち、八時少し前て暗くなってから中蝉赫こつた。伊

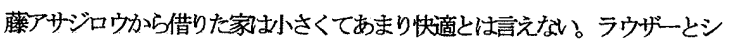
エミットとそこで緒こ外をする。

このことから、アーネスト・サトウが、明治28年 (1895) には日本人 の伊藤アサジロウ」から家屋を借りていたことがわかる。そして、ア 一ネスト・サトウは、翌明治29年 (1896) に、後に湖畔で初の大使館別

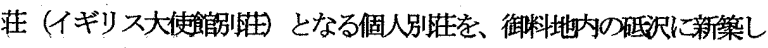
ている。この趾につい、アーネスト・サトウおよびダスタン夫人の 日記には、完成までの経過か论のように記されている ${ }^{18)}$ (明治28年9月17日:サトウの日記より)

朝 グートシュミットのボートに乗って、私分新しく家を建てている㸴沢 まで十二分か加漕ぐ。

(明治28年10月20日: ダヌタン夫人の日記より)

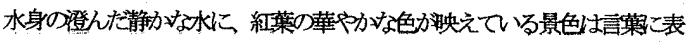
せないほどの美しさであった。私たちは湖を真力直ぐ浀き渡り、片。 アーネスト・サトウの新しに家の場所まで彳亍った。そこで撕て職人たち が就とうに働、ていた。

(明治29年5月30日:サトウの日記より)

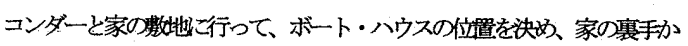

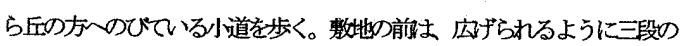
テラスを作ることにする。

(明治29年7月 15 日 :サトウの日記より)

表2. 明治29年, 30 年 外国人呺推

\begin{tabular}{|c|c|c|}
\hline \multicolumn{3}{|c|}{ 明治29年 (1896年) } \\
\hline & 所有者 & 局書き \\
\hline 1 & アーネーネト・サトウ別肚 ${ }^{* 1,2}$ & 英国公使 \\
\hline 2 & 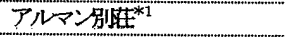 & \\
\hline 3 & ヴュゴ゙ンブルック別杜*1 & オーストリア公使 \\
\hline 4 & 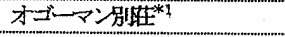 & \\
\hline 5 & カークート涓 ${ }^{* 2}$ & 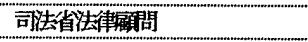 \\
\hline 6 & 力口別胜*1 & スヘイン書馆 \\
\hline 7 & グートシュミット別杜*1 & 在日ドイソ公使 \\
\hline 8 & シャパイー别甠 ${ }^{* 1}$ & 在日ロシア公使 \\
\hline 9 & 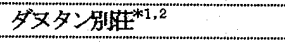 & 在日ジルキー公使 \\
\hline 10 & トーマス・グラバー賀庄*1 & \\
\hline 11 & イザヘラ・ビショップ別昳 ${ }^{* 2}$ & 旧﨡イザヘラ・バード、英国人 \\
\hline 12 & プルータルス別潵 & フランス公束館 等畫㲹官 \\
\hline 13 & ラウザー別茎*1 & 英国公使領一等澅汇官 \\
\hline 14 & レーンホルム别昳 ${ }^{* 1}$ & 帝国大学ドイツ語赾研 \\
\hline \multicolumn{3}{|c|}{ 明治 30 年 (1896 年) } \\
\hline & 所 有者 & 有書き \\
\hline 1 & アーネスト・サトウ別茫 ${ }^{* 1,2}$ & 英国公使 \\
\hline 2 & オコーマ别泩 & \\
\hline 3 & カークート別清*1 & 司法省洼律㩔問 \\
\hline 4 & ダフィン别杜 $x^{13}$ & \\
\hline 5 & ダヌタン別在 ${ }^{* 1,2}$ & 在日ベルギー公便 \\
\hline 6 & ドュ・ドレズ祸甠*1 & フランス公使館三等畫記官 \\
\hline 7 & トース・グラバー別杜 ${ }^{11}$ & \\
\hline 8 & 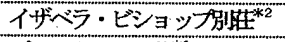 & 貹イザララ・バード、英国人 \\
\hline 9 & プルータルス別庄 ${ }^{* 1}$ & フランス公使伯官 等書䛎官 \\
\hline 10 & へロット別壮*1 & アメリカ公使館書記官 \\
\hline 11 & ホンディー別杜 & \\
\hline 12 & メ侣㢈*1 & ベギー公使館等書記官 \\
\hline 13 & リスポ罗唯*1 & ブラジル特命全篗公使 \\
\hline
\end{tabular}

*1: [アーネスト・サトウ公吏日記I, II』より

*2:『ベルギー公使夫人の明治日記より
家への道省がらダヌタン男爵夫人を祊ねる。雨力強く降っていたのでラ ウザーと昼食するのを部めて、真直く家一行った。家の中はひどく散らか

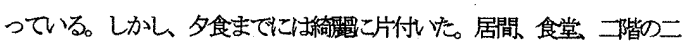
部屋に障子が圾まり、階段もできて建貝の残りも届い。

日記にある「コンダー」とは、建築家ジョサイヤ・コンドルのことで、 アーネスト・サトウの別萑をコンドルか設計した可能性も考えられる。 また、その他の別郝有者もほとんどが公使、書記官などで、他にも建 築家によって別痤の設計が行われていた可能生も考えられる。

外国人別栍には、アレキサンドル・カークードやアーネスト・サトウ の別胜ように 個人別胜として新筑されたもののほか、借主が固定され ず每年のように変る別栍も存在していた。その様子について、アネス ト・サトウの日記には、次のように記されている゙1。 (明治 31 年7月 18 目)

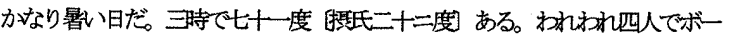
卜を漕ぎ、家の北西の方向にある佂で行って、そこから元プールタレスの家 だったボンディーの家まで行く。

(明治 31 年7月 19 日)

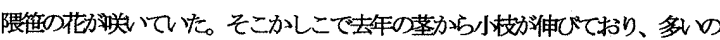
は二本も出て、た。㷌りは湖の北岸沿、漕ぎ、ド・ボンディーの元の家のと ころまできて、そこから湖定横切って家へ戻る。

(明治 32 年 5 月 27 日)

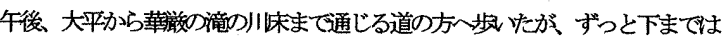
降りなからた。そのあとライデンの家に行った。そこは去年までドュ・ドレズ ネが徣りていた家だ。ホテルの別館とへロッドの家とオコーマン夫人の家が間 もなく完成する。

中弾寺湖畔に建設された外国人別胜の位置をみると、最初こ建竞され た2軒の別性㥓の地で、日光市内より九十九折りの新道を登り、二 荒山神社付近の中宮祠の中心街を抜けた、湖の北岸に位置していた。公 使の日記からは、北岸に位置していた別痤として、前述の 2 軒以外にダ

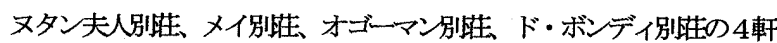

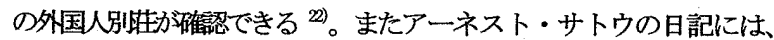
明治 33 年(1900)に湖北岸に「外国人別荘地帯」が形成されていた ことが記されている ${ }^{23)}$ 。

(明治 31 年 6 月 19 日)

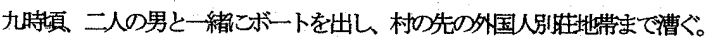

それから帆を上げて亘蒲の浜までゆっくり帆走した。

この記述から判断すれば、最初の別荘が中禅寺湖畔に建ってから 10 年程度のうちに、湖畔に「外国人別荘地帯」が形成されていた ことがわかり、中禅寺湖畔が、明治時代後期にはすでに别荘地とし

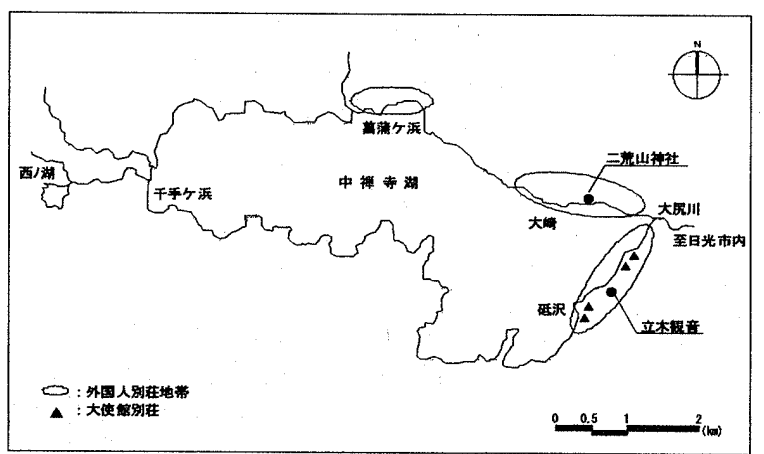

図 1 明治後期の中禅寺湖畔外国人別荘配置図 
て繁栄していたらしいことがわかる。

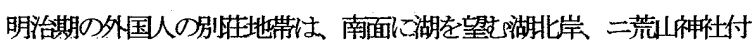
近の多崎を中心に発展し、その後䟚は、ア一ネスト・サトウの別壮が 新筑された、湖の東岸である砥沢へと増加して行ったといらことができ

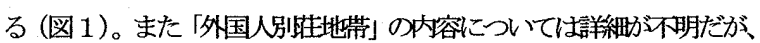
一つ地域こある程度以上の別甠がかたまって存在していたらしいと考 えることは可能であろう。

\section{3. 大正期の外国人別荘地}

東京・日光間、及ひ叫禅寺湖までの明治以降の交通の発展をまとめた

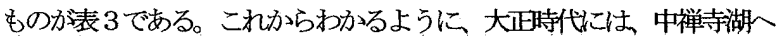
の交通の便㴔速に発達している大正 6 年 (1917) には、日光・馬返 間に日光自動車株式会社の乗合自動車潤業し、大正14年 (1925) には 馬返・中禅寺湖間润開通し、乗合自動車で中禅寺湖まで行くことができ るようになった。

また、中禅寺湖における郵便業務や電信業務については、明治期 から整備されている（表4）。アーネスト・サトウの日記には、こ れらの整備状況について次のように記されており、外国人公使らの 働きかけがあり、整備が早期に進んだことも考えられる ${ }^{24)}$ (明治29年3月 3 日)

近くモスクワに向けて出発される伏見宮殿下のために開かれた公式の送 別晚餐会に出席する。隣の席は土方だったが、もう片方の席は山県の出 席を予定して空けてあった。白根が中禅寺への電信線は、我々が夏にそ こへ行くまでには必す開通すると言った。横浜の領事館の電話も四月に は開通するそうだ。

(明治 30 年 12 月 9 日)

私が三宮宛に手紙で中禅寺の私の家の前の道路のことを書いたので、そ の件で長崎省吾〔式部官〕が訪ねてきた。その機会に、西男爵、小村、 都筑は、私の訪問に対して答礼がないと言って执た。

郵便や電信の業務が比較的早い時期に整備された理由には、中 禅寺湖畔が、外交官らの別茫地として早くから発展しており、その 為に、これらの必要性が生じたことが考えられる。郵便や電信の整
表 3 中禅寺湖略歷年表 (交通関係)

\begin{tabular}{|c|c|c|}
\hline 年号 & 西暦 & \\
\hline 明治 17 年 & 1884 & 日光一円宮内省御猙場に指定 \\
\hline 明治 18 年 & 1885 & 東京〜宇都宫間に鍷道開通 \\
\hline 明治 21 年 & 1888 & 小倉山・野州原及び奥日光が宮内省御料地となる \\
\hline 明治 22 年 & 1889 & 馬返〜中禅寺間の山道に九十九折りの新道を開拓 \\
\hline 明治 23 年 & 1890 & 宇都宫〜日光間の鉄道全面開通 \\
\hline 大正 2 年 & 1913 & 日光駅 馬返間に日光電気軌道が 全面開通 \\
\hline 大正6年 & 1917 & 日光自動車侏は日光〜馬返間に乗合自動車開業 \\
\hline 大正 14 年 & 1925 & 馬返〜中禅寺間の軌道が执楅されて乗合自動車運行 \\
\hline 昭和 4 年 & 1929 & 東武鉄道日光線の浅草〜日光間が全線開通 \\
\hline 昭和7 年 & 1932 & 馬返〜明智平間に日光登山鉄道が開業 \\
\hline 昭和8 8 年 & 1933 & 中禅寺湖間に自動車専用道路開通 \\
\hline
\end{tabular}

『奥晃史抄』 ${ }^{20)}$ 上り作成

表 4 中禅寺湖略歴年表 (通信関係)

\begin{tabular}{|c|c|c|}
\hline 年号 & 西曆 & \\
\hline 明治20年 & 1887 & 切手売下所設置 \\
\hline 明治29年 & 1896 & 電信事務開始 \\
\hline 明治31年 & 1898 & 郵便受取空口引取事務開始 \\
\hline 明治 35 年 & 1902 & 電話通話事務開始，県内初の官設公衆電話設置 \\
\hline 明治 36 年 & 1903 & 電話交換事務開始 \\
\hline 大正5年 & 1916 & 菖蒲分浜電力林式会社発電所設置 \\
\hline
\end{tabular}

『奥晃史抄』 200作成

備は、夏季に長期滞在する外交官などを含む外国人にとって、有効 な役割を果たしたことであろう。

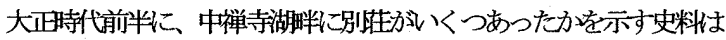
なく、別庄の状況を確認することは不難であるが、大正末期に作成さ れた「中禅寺湖明别性見取り図」(図2)には、外国人别性が39軽、 日本人別胜数が 3 軒の、合計 42 軒の別甠が記されている から、明治末期功大正初期に加てても、着実に外国人别胜力増加し ていらたことがわかる。また、数は少ないが日本人の別胜も確珰でき る。日本人の別胜には、岸本别胜、德柺唯、大塚别胜の3軒がある。

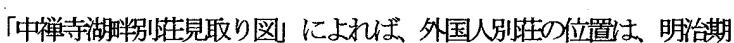
には、湖尻を中心に建てられていたが、大正末期にはさらにその範井 が広がり、菖浦が浜の方まで建設されていたことも確認できる。

大正末期から昭和初期には，大正11 年 (1922) に建設されたフラン ス大使館㔚甠のほか、いくかの大使馆の別性も建設されている。外

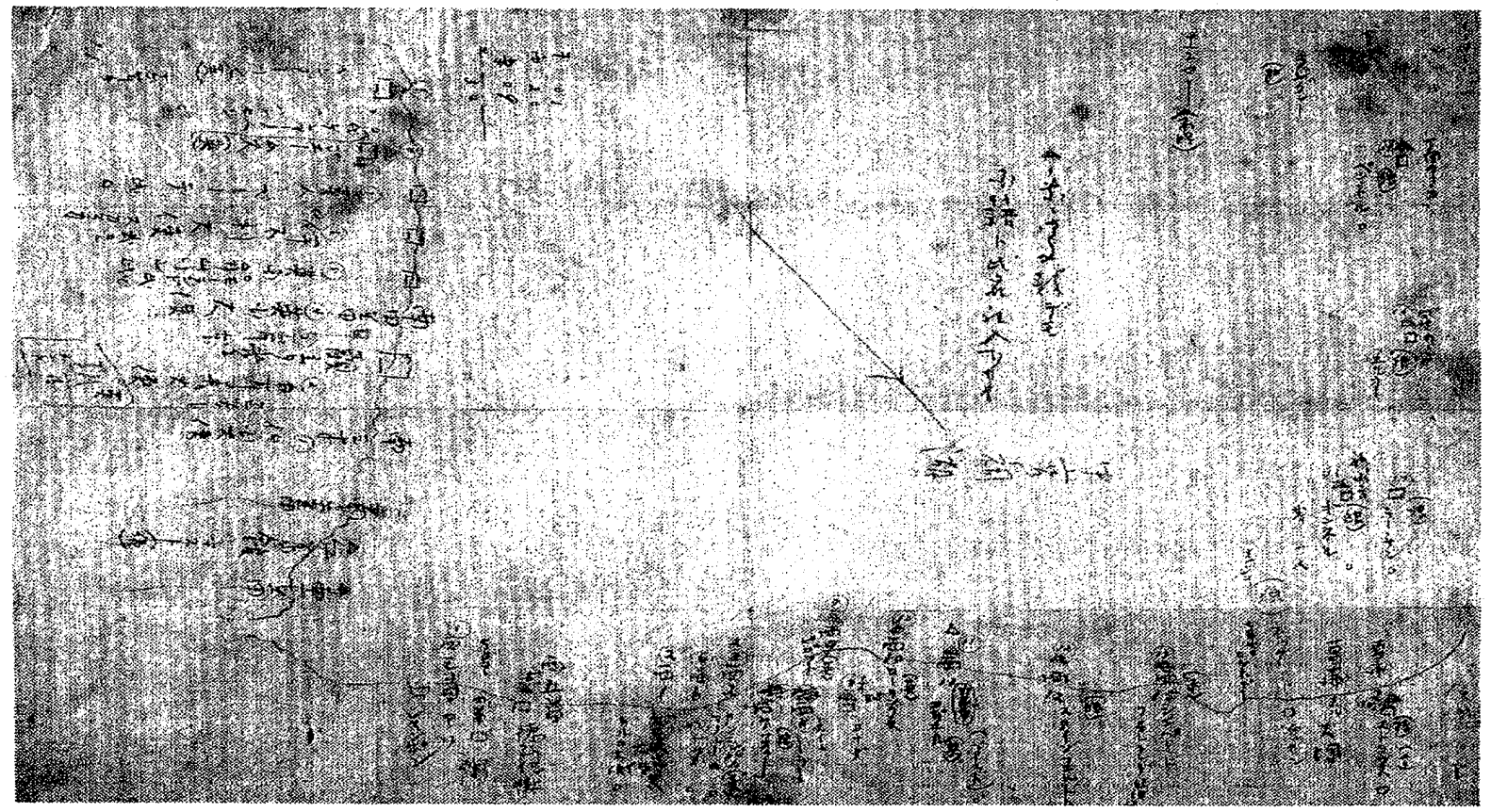

図2 中椫寺湖畔別萠見取り図 
国人の個人別杜に留まらず、大使館の別胜が建設されたことは、中禅 寺湖㫠の别性地の性格を考学えうえでも注目される。

\section{4. 東京アングリング・エンド・カンッリ一・俱楽部と昭和期の} 外国人別荘地

大正元年 (1912) には、後に中禅寺湖畔の外国人別性地における活 動の中心的梅点ともなる、東京アングリング・エンド・カンツリー俱

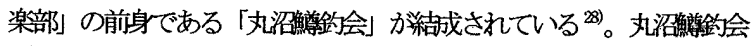
は 大正13年項 (1924) に代表を侯爵・鍋鳥直映、理事を神戸のハン ター財閥のハンス・ハンター20)として、東京アングリング・エンド・ カンッリー俱楽部!(以下, T.A C.とのみ記す) に発展している。

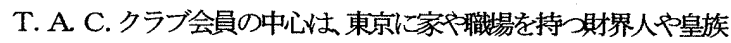
達であった (表5)。クラブの事務局は、ハンス・ハンターの会社があ った東京标坂に置力れていた。のことから、土地貸貸や建築部画 などが、東京で行われていた可能性も考えられる ${ }^{0}$ 。クラブの名称に 「日光」ではなく東京】が使われたのも、おそらくそのことに由来 するのであろう。

T.A. C.のクラブ会則には、次のような内㟮記されている。 本俱腺部《野外運動を奖厉㸝るため、鱒验ゴルフ場等を設置し、 なかんずく鱒釣りを紳上的に行うことを主なるものとする。

表5 T.A.C.クラブ会員

\begin{tabular}{|c|c|}
\hline 後援 & 秩父宮、朝香宫、東久洒宮 \\
\hline 会長 & 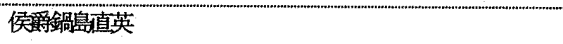 \\
\hline 副会長 & 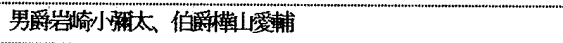 \\
\hline 運営委員長 & ハンス・ハンター \\
\hline 名誉幹事 & ハンス・ハンター \\
\hline 名誉会計 & 子爵秋元春朝 \\
\hline 名兴会貣 & 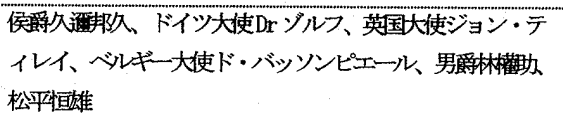 \\
\hline 普通会買 & 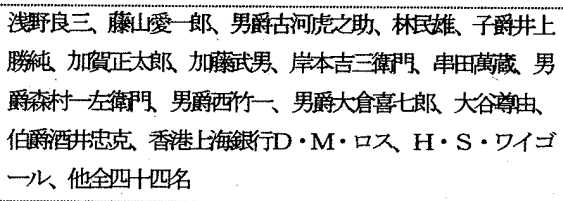 \\
\hline 特别会員 & 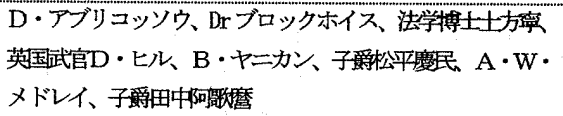 \\
\hline
\end{tabular}

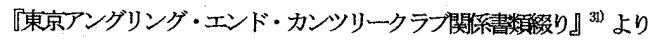

会則によれば T.A. C.がアングリング (フライフィッシング) を主たる目的としていたことがわかる。またほかに、ゴルフ場、運 動場、及び会員の為の別性を建設する計画などもたてている22)。T. A. C. は，東京の財界人、皇族、外国人の中禅寺湖㫠を核にした交 流のクラブと考えてよいだろう。

昭和に入ると、大正末期こ作成されたT. A. C. の計画が実現に移さ れていくまた、昭和 3 年 (1928) には、イタリアおよびべル゙ー大

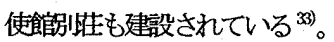

T. A C.による施設の建設柱，大正 14 年(1925)に帝室林野局力 ら借受けた西ノ湖畔に、畕漁昜のための見張り小屋、及ひ㦈漁池を 設けることから始められた ${ }^{31)}$ 。そして大正 15 年(1926)には、クラブ 会員の娛楽場となるクラブの本建筑を中禅寺湖㫠の西端である千手 ケ浜に建設するため、輪王寺宛に借地影洨、提出している。そこに は、借地目的か次のように記されている゙の。

俱楽部の運営上ぜひともその境内の一部を借用したいっつては 贵㩆紳

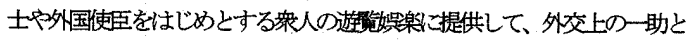

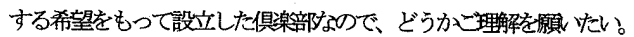

これによれば、クラブ建物の建設目的が、貴影神士や外国使臣の交 流の場として、有效な役割を果たすことが考えられていたことがわか る。またこのことは、日光・中禅寺湖の外国人沜惟地のもつ意味が、 軽井沢の別甠地とも性格を異にしていたらしいことをうかがわせる。 この建物は、実際こ建てられることなく計画だけで終わってしまった が、アントニン・レーモンドによって、大正15年(1926)に設計された 「日光中禅寺アングリングクラブ」の図面 (図3) が残されているが。 実祭のT. A. C. 会員たちの娛楽場としての建物は、ハンス・ハンタ 一の別㾋のあった大㥓の地に、西六橎胜として昭和2年(1927)に建 設された。

娛楽場の建設場所が、千手久洪加大崎になぜ変更されたがは定か でない゙、当時、湖尻から千手ケ浜门の交通手段はボートしかなく、 また外国人別挂との距離も遠く離れており、これらの理由から、クラ ブの妩泉場建設の教地が、より便利な地である大崎一変更されたもの と思机れる。

西六橎蜼の建物については、アントニン・レーモンドの設計にな

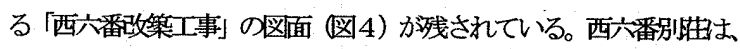
事実上はT. A C.のクラブハウスとして使用されていたが、こ建物

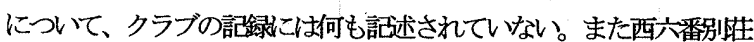
には 先の「旧光中禅寺アングリングクラブ」の計画少には存在しな

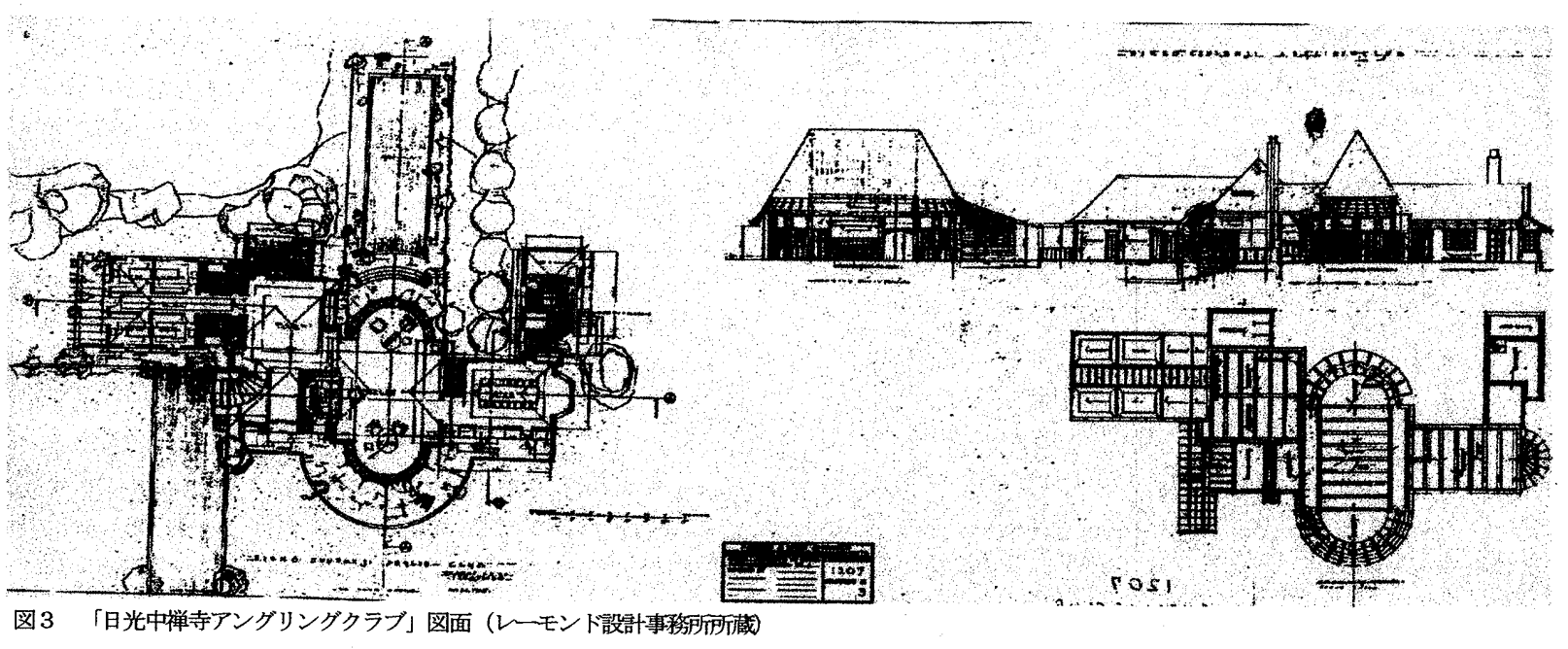


かった、クラプ理事であるハンス・ハンター専用の和室が2階し設け られている。このことや、この場斦がハンス・ハンターの別荘があっ た地であることを考えると、この施設は、ハンス・ハンター自身が、 クラブのために個人所有の土地を提供し、さらに建物を建喑したもの とも考えられる。

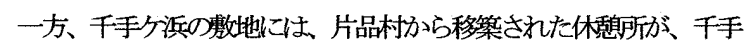
クラブハウスとして昭和2年 (1927) に建てられている ${ }^{60}$ 。その後、 クラブハウス西六勫胜の雨燐にも、ハンス・ハンターの所有地に、 会員家族のための別脽として西二橎性か时召和6年 (1931) に、西一

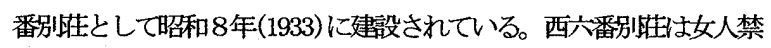
制であったが、西一番、西二橎时花には、クラブ会員の女性家族も宿 泊できるようになっていた。西一番、西二番と西六橎別性は、一階 にリビングやダイニングと、二階こベットルームを持っており、クラ ブ会員のための休想所や缩泊施設としての役割を果たしていた。

以上のように、会員のための別甠は着害に建設されたが、当初の計画 にあったゴルフ場、及ひ運動場などは、その後も実現されることがな か⿰た。

T.A. C. 纵順調にクラブ経営を進めていが、昭和 15 年(1940) に T. A C. . 中心的存在であり、各国外国人の社交の場となって いた西六橎唯を焼失している。その後、同年にハンス・ハンター は、千手ケ浜の輪王寺借地内に、ハンス・ハンター別模を建設して いる。ちな外にこの別胜法，中禅寺湖畔の外国人別蛙として、最後 の建物になった、しかしやがて、戦争が始まり、外国人のクラブ会 員か漒制退去させられるようになると、華やけた空気が段々となく なり、T. A. C. も昭和19年 (1944) に解散している3゙。

\section{5. まとめ}

明治中期から昭和戦前にかけての中禅寺湖畔における外国人別
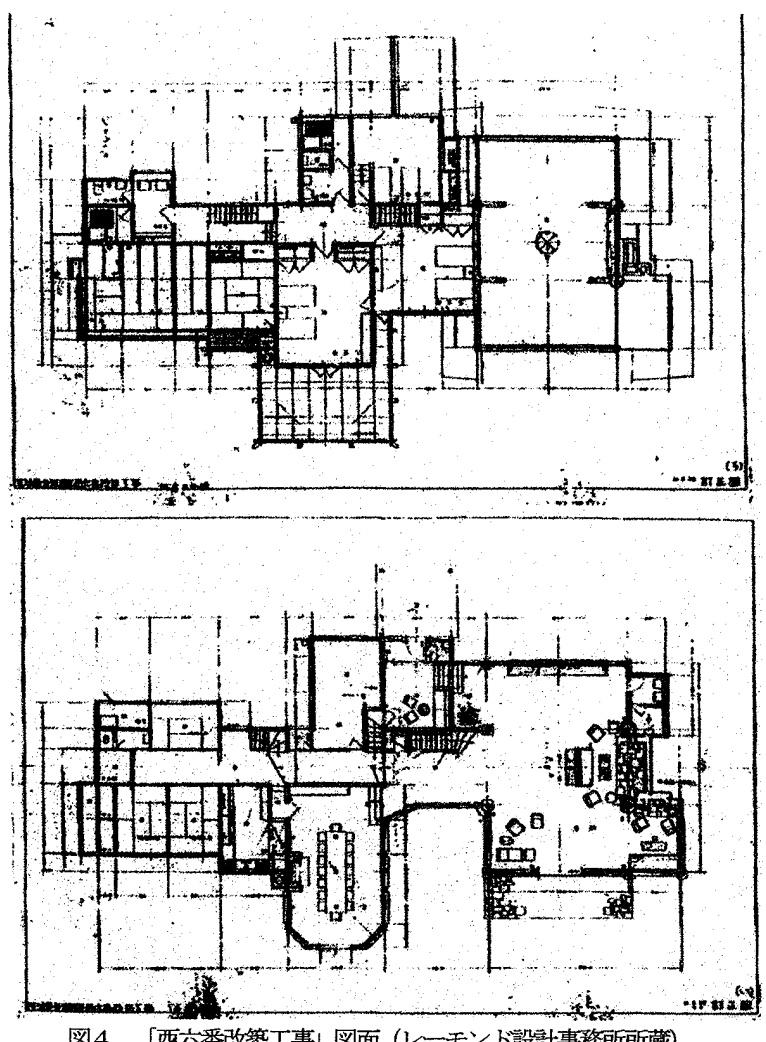

図4西六番改築工事! 図面 (レーモンド設計事務所所蔵
荘について、その避暑地としての形成や発展経緯について検討した。 その結果、以下の点が明らかになった。

1. 中禅寺湖畔の外国人別荘地は、明治 20 年頃 (1887) より公使, 外交官らを中心に形成されていき、明治 30 年頃（1897）には 外国人別荘地帯と呼ばれる程の規模に成長している。

2. 大正期には日光・中禅寺湖間の乗合自動車交通も確保される など、交通が便利になり、外国人別荘地としてさらに発展して いった。

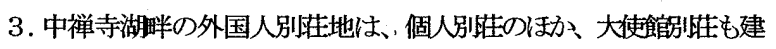
設されており、公使、外交官ら、上流階級の外国人を中心とした 別荘地の性格をもっていた。

4. 大正元年 (1912) には、フライフィッシングといら外国人特有 の娛楽を目的とした「丸沼鱒釣会」が設立され、大正 13 年 (1924) には、「東京アングリング・エンド・カンツリー俱楽部」へと 発展しているなど、中禅寺湖畔の別痤地帯が、日本人貴顕紳士 や外国使臣の交流の場として大きな役割を果たしていた。

5. 中禅寺湖畔の別荘所有者の大部分が外国人であったという理由 もあり、第二次世界大戦が始まると共に、別荘地として衰退の 一途をたどっていった。

本論文をまとめるにあたっては、レーモンド設計事務所の的埜教 介氏から図面の提供をいただいた。また、「東京アングリング・エ ンド・カンツリー俱楽部」史料の閲覧では、日光市立図書館のご協 力を頂いた。なかでも、日光市役所の福田和美氏には多くのことを 教えて頂いた。お世話になった方々に深く感謝いたします。ほかに も、ヒアリングなどで多く方々にお世話になった。

[注]

1）日光市役所編『日光市史』日光市役所 昭和 54 年。ここでは、日光およ び奥日光の歷史がまとめられている。奥日光に関しては、交通や郵便局 等の設㯰、土地所有区分が中心であるが、外国人の見た日光として、外 国人の記述を記している。

2）安島博幸・十代田朗『日本別荘史ノート』住まいの図書館出版局 平成 3 年。ここでは、日本の高原別壮地のひとつとして日光・中禅寺湖を取 り上げ、外国人別㽵地としての中椫寺湖をまとめている。

3）福田和美『大日光第65〜67』日光東照宮 平成3年。ここで注、避暑地 日光成立史として、日光・中禅寺湖畔の外国人避暑地としての成立ちを まとめている。

4) 明治18年 (1885) のカナダ生まれのイギリス教会牧師A・C・ショウと J ディクソンか㘪井沢を訪れたことに始まる。翌年から彼らは毎夏を軽井沢て過 ごすようになり、明治20年 (1887) にショウ牧師廃業した旅宿を買い大场山 に移筑することによって品性を建てた。初期材外国人避暑地として発展し、避 暑地といら概合が定着した軽井沢であったが、日本人による大きな別肚地開発

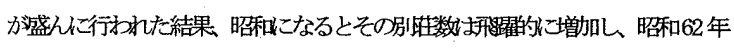
(1962)には1万户を超えている。

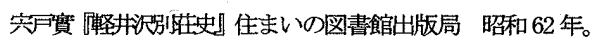
前出『日本別荘史ノート』P88〜95

5) 明治期までは湖判に6 軒の旅館がひしめいて営業していたものの、大正 3 年 (1914 年) の大火によりすべての旅館が全焼したことをきっかけに、 場所を移転する旅館も現れた（米屋旅館へのヒアリングによる)。

6）鈴木ホテル：[杤木県鉢石町の鈴木喜惣次経営の鉿木ホテル、明治四, 五 年より十五，十六年頃迄人力車、馬車の立場を兼外外人を宿泊さす」運輸 省鉄道総局観光橦『日本ホテル略史』運輸省観光部 P8 昭和 46 年。 金谷カッテージイン: 「明治六年六月東照宮の楽人金谷善一郎米人ドクト ル・ヘツボーンの指導により夏期中田母澤御用氐近くの四軒町にありし 
自宅及隣の家屋を借り集め避暑地カツテイジ・インを開業す。」前出『日 本木テル略史』P10

7）「明治二十七年四月日光中禅寺湖㫠こレーキサイドホテル開業す。前出『日本 ホテル略史』P44

8）『富士星ホテル八十年史』富士屋ホテル林式会社P44 昭和33年

9）日光金谷ホテルは明治 41 年頃に自家用発電所を設圈している。(金谷真 一『ホテルと共に七拾五年』金谷ホテル栻会社 P29 31 昭和 29 年。

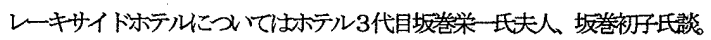
初子氏は昭和20年に圾巻栄 氏と結昏し、ホテルのフロントなどを勤好てた。

10）前出 坂巻初子氏談

11）前出『日光市史』下巻 $P 691 \sim 692$ 昭和 5 年 (1930 年) に国際観光局が運輸省に設置され、外客誘致事業は、 「国際䂓光政策」の1つとなった。これ受けて日本各地でリゾートホ テル建設が盛んになり、現在へと続くリゾート、観光地である上高地 蒲郡、川㴎、唐津、赤倉等は国際観光局か瀚㳬した大倉資金を用いた「国 際観光ホテル」として、新たにホテル建設が焦しだここれらのホテルは、 最初から外客誘致を目的として建設された施設であるが、雲仙や阿蘇 河口湖、松島、そして中禅寺湖などの既成観光地、リゾート地でも新た な外客向け施設の必要性から、この国際観光ホテルが建設された。

12）前出『ホテルと共に七拾五年』P62 63

13）前出『大日光 $66 』 P 76$

14）エリアノーラ・メアリー・ダヌタン著 長岡祥三訳『ベルギー公使夫人 の明治日記』中央公論社 $\mathrm{P} 64$ 平成 4 年

15）外務省外交資料館所藏資料『外國人二シテ日本人名義 Э以ッテ土地又心 家屋习所有スルモノ/調查』、外國人所有土地家屋営業關慗—臨表」

16）前出『心ルギー公使夫人の明治日記』 アーネスト・サトウ著 長岡祥三訳『アーネスト・サトウ公使日記 I』 新人物往来社 平成元年

アーネスト・サトウ著 長岡祥三、福永有雄訳『アーネスト・サトウ公 使日記新人物往来社 平成 3 年

17）前出『アーネスト・サトウ公使日記 I』P42

18）前出『ベルギー公使夫人の明治日記』 $\mathrm{P} 97$ 前出『アーネスト・サトウ公使日記 I』P150、165

19）前出『アーネスト・サトウ公使日記 I』P159、166、169、173 前出『アーネスト・サトウ公使日記I』P106、135、137、

20）前出『ベルギー公使夫人の明治日記』P66.119、

21）前出『アーネスト・サトウ公使日記II P137、252

22）前出『アーネスト・サトウ公使日記II』P135〜137

23）前出『アーネスト・サトウ公使日記II』P118

24）前出『ア一ネスト・サトウ公使日記 I』P113、301

25）奥日光経友会『奥晃史抄』奥日光経友会 平成 2 年

26) 前出『奥晃史抄』

27）大島久治作成「中禅寺湖畔别荘見取図」大島久夫氏藏

28）『東京アングリング・エンド・カンツリー俱楽部関係資料経り』日光市立 図書館蔵、丸沼蘚釣會々員名簿」による会員には、今村慗三、子爵石川

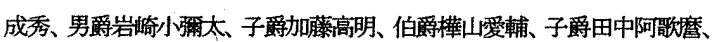

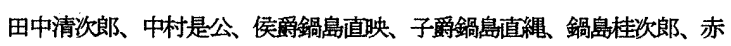
星鉄馬、西園寺八郎、男爵古川虎之助、伯爵酒井忠克、佐藤受箞、士方 寧 土方久徴、ハンス・ハンターの名が記されている。

29）ハンス・ハンター:父はエドワード・ハズレット・ハンター（慶応元年 : 1864 年来日。造船所勤務の後、 $\mathrm{E} \cdot \mathrm{H} ・$ ハンター商会を設立。その後明治 12 年: 1881 年に大阪鉄工所[現日立造船を設立。神户の自邸佉、旧ハン ター氏邸として移筑され国の重要文化財に指定されている)。明治 15 年 （1884）にE・H・ハンター次男として生まれる。19歳にしてロンドンの 鉱山学枌で治金学を修內、日本に帰国後家業を手伝う傍らいくつかの鉱 山経営を営む。

30）前出『東京アングリング・エンド・カンッリー俱楽部関俰資料棳り』内 大正 14 年 1 月 20 日付借地顕承諾畫」には俱楽部の所在地として東京
市赤坂区榎坂町壱番地が記載されている。

31）前出『東京アングリング・エンド・カンツリー俱腺部関係資料緅り』内 大正 15 . 年 3 月 13 日付 大島久治発倉場富三郎宛の手紙に記された俱 楽部会員名。

32）前出『東京アングリング・エンド・カンツリー俱楽部関保资料緅り』内 大正 14 年 7 月 15 日付「借地額書」には、俱楽部運動場及鱼場計画書 として、1.20 万坪にゴルフ場を設置し、周囲に射慗場、弓術場、野球場、 を遂次併置する。2. 西ノ湖、外山澤川を恙魚場とし会員の釣り場とする。 3. 俱楽部を建設し会員の宿泊施設と室内娛泉場とする。4.会員の別的 を建設するため、道路と飲料水の設備を完備させる。の4つが記されて いる。

33）イタリア大使館別㢈: 昭和 3 年建設、設計者アントニン・レーモンド ベルギー大使館別甠 : 昭和 3 年建設、設計者不明

34）前出『東京アングリング・エンド・カンッリー俱腺部関係資料棳り』内 大正 14 年6月 17 日付「借地願 見張番小屋・盖魚池」には、帝室林野 局東京支局長帝室林野局技師 佐々木和策宛に、見張番小屋平屋建坪 19 坪、物圈 6 坪、及ひ羔魯池 3 面を大正 14 年 6 月より大正 18 年 12 月まで の5ケ年間借りるための借地顛いが記されている。

35）前出『東京アングリング・エンド・カンツリ一俱楽部関倸資料緅り』内 大正 15 年 2 月 21 日付「穓貸借契約書」の中で千手ケ浜の土地に対して 輪王寺門跡今井徳順宛にて貸貸借契約を結んでいる。その借地目的と しては、1. 俱楽部並二之二附迶スル建物及會員住宅設置。2. 建告物八 凡テ風致二支障ナキ構造夕ルベキモノトス。3.他教徒ノ布教傳道用二供 セザルコト」と記されている。

36）前出『東京アングリング・エンド・カンツリー俱楽部関倸資料綴り』内 昭和 2 年 9 月 17 日付「受頒佂」には俱楽部会員の今村繁三所有の片品村 にある木造板套平屋建て一棟が俱楽部に寄䁌されている。この建物が千 手ケ浜に俱楽部の休嚊所として移築されたと考えられる。

37）前出『東京アングリング・エンド・カンツリー俱楽部関俰資料棳り』内 昭和 19 年 4 月 30 日付「借地返僄顆にには、陳者当クラブ名義二テ拝借 中ノ奥日光御料地ノ儀今般当クラブ閉鎖仕侯二付返地申上度茲許同封借 地返還顆式通提出仕候間何卆御受理成下度此段貴意申侯也」記されて

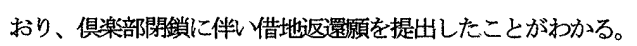

（2002年 4 月 10 日原稿受理，2002年 5 月 29 日採用決定） 